\title{
Cationic Graft Polymerization of 2-Oxazolines on Cellulose Derivatives
}

\author{
Isao IKEDA, Yoshiaki KuRUSHIMA, ${ }^{*}$ Hisataka TAKASHIMA, ${ }^{* *}$ \\ and Kimihiro SUZUKI \\ Department of Applied Chemistry, Fukui University, \\ Bunkỳo, Fukui 910, Japan
}

(Received July 21, 1987)

\begin{abstract}
Cationic graft polymerization of 2-oxazolines on cellulose derivatives such as chlorinated cellulose (Cell-Cl), cellulose acetate halogenacetate (AcCell-AcX), and cellulose tosylate (Cell-OTs) was investigated. With Cell-Cl the successful graft polymerization of 2-methyl2-oxazoline (MeOXZ) required the presence of potassium salt but with AcCell-AcX and Cell-OTs it proceeded without the salt. The reactivity of halogens in graft polymerization of $\mathrm{MeOXZ}$ on halogenated cellulose derivatives increased in the order of $\mathrm{I}^{-}>\mathrm{Br}^{-}>\mathrm{Cl}^{-}$. This is explained by the nucleophilicity of halogen ions compared with that of MeOXZ. Graft copolymers prepared with AcCell-AcX were hydrolyzed by $0.5 \mathrm{~N} \mathrm{NaOH}$ solution to isolate the branched poly(MeOXZ). The molecular weight of the branched poly(MeOXZ) measured by GPC was in the range of 380 to 3510 depending on the reaction conditions. 2-Oxazoline (OXZ) did not graft-polymerize with halogenated cellulose derivatives, but graft-polymerized with Cell-OTs.

KEY WORDS Cationic Graft Polymerization / 2-Oxazolines / Cellulose

Derivative / Graft Copolymer / Poly $(N$-acylethyleneimine) / Halogen

Exchange / Linear Poly(ethyleneimine) /
\end{abstract}

Ring-opening polymerization of 2-oxazolines has been widely investigated by. Saegusa and co-workers. As initiators they used low molecular compounds such as methyl tosylate and methyl iodide to elucidate the mechanism of the polymerization ${ }^{1}$ and several polymeric derivatives to synthesize the block and graft copolymers. The polymeric derivatives used were tosyl or mesyl derivatives of poly(ethylene oxide), ${ }^{2} \alpha, \omega$-polybutadiene glycol, ${ }^{3}$ cellulose ${ }^{4}$ cellulose acetate,${ }^{4}$ and ethylenevinylacetate copolymer, ${ }^{5}$ 1-chlorobutadienebutadiene copolymer, ${ }^{6}$ chloromethylated polystyrene, ${ }^{7}$ bromoacetylated hydroxyethyl cellulose $^{8}$, etc. Furthermore, the product copolymers were hydrolyzed with concentrated sodium hydroxide solution to convert the poly $(N$-acylethyleneimine) component into poly(ethyleneimine) (PEI). The converted copolymers were used as an adsorbent of heavy metal ions. ${ }^{7}$

As previously reported, ${ }^{9,10}$ we demonstrated that graft and/or cross-linked copolymers were prepared by the reaction of commercial PEI with cellulose derivatives such as $\mathrm{Cell}-\mathrm{Cl}$, AcCell-AcX, and Cell-OTs or bromoacetalized poly(vinyl alcohol). The product copolymers were used as adsorbents of heavy metal ions and supporting materials of enzymes. Apparently, these three cellulose derivatives are also the initiators of 2-oxazoline polymerizations. In the graft polymerization of 2-oxazolines the prepared copolymers can have the well-defined structure by the conversion of

* Present address: Research and Development Center of Unichika Ltd., Kozakura, Uji, Kyoto 611, Japan.

** Present address: Urase Goudou Senkou Ltd., Kaminaka-cho, Sabae, Fukui 910, Japan. 
$\operatorname{poly}(N$-acylethyleneimine) to linear PEI but it is difficult to control the molecular weights of branched polymers contrary to the reaction of commercial PEI. Thus there have not been studies concerning the structures of graft copolymers such as the length of branched polymer and the degree of branching. On the basis of these points, we also investigated the polymerization of 2-oxazolines by these cellulose derivatives. The graft polymerization of 2-oxazolines was performed homogeneously in DMF, nitrobenzene and benzonitrile. The present article describes (1) the differences of the reactivities of 2-oxazolines on the three cellulose derivatives and (2) the determination of molecular weight of branched poly ( $N$-acetylethyleneimine) (poly(MeOXZ) separated from the copolymers prepared with AcCell-AcX and apparent initiator efficiency of AcX groups.

\section{EXPERIMENTAL}

\section{Materials}

MeOXZ was purchased from Aldrich Chem. Co. and purified by distillation. OXZ was synthesized according to the method of Wenker, ${ }^{11}$ Franco, $^{12}$ and Saegusa ${ }^{13}$ and purified by distillation. Cell-Cl, AcCell-AcX, and Cell-OTs were synthesized by the following methods. Cell- $\mathrm{Cl}^{14}$ : regenerated cellulose $(3 \mathrm{~g})$ prepared by the saponification of cellulose acetate $(\overline{\mathrm{DP}}=169)$ was dissolved in a mixture of chloral $(10 \mathrm{ml})$ and DMF $(100 \mathrm{ml})$. Then methanesulfonyl chloride $(11.6 \mathrm{ml})$ was added to the solution and reacted for 4 hours at $75^{\circ} \mathrm{C}$ under a nitrogen atmosphere. The products were precipitated in water, neutralized with $10 \%$ sodium carbonate, filtered off, washed with water and dried in the vaccum oven. $\overline{\mathrm{DP}}$ of Cell- $\mathrm{Cl}\left(\mathrm{Cl}_{\%}^{\circ}=26.1\right)$ was 48 . AcCell-AcX ${ }^{15}$ : cellulose acetate $(5 \mathrm{~g})$ was dissolved in halogenated acetic acid at $60-85^{\circ} \mathrm{C}$. Then sodium acetate $(2.5 \mathrm{~g})$ and acetic anhydride $(11.2 \mathrm{~g})$ were slowly added to the solution and the reaction mixture was maintained at $80^{\circ} \mathrm{C}$ for
5 hours. The products were precipitated in water, washed with water until the free acid was not detected and purified by reprecipitation (methylene chloride/methanol). $\overline{\mathrm{DP}}$ of AcCell-AcCl (DS of $\mathrm{AcCl}=0.27$ ), AcCell$\mathrm{AcBr}$ (DS of $\mathrm{AcBr}=0.22$ ), and AcCell-AcI (DS of $A c I=0.19$ ) were 56, 33, and 48, respectively. Cell-OTs ${ }^{16}$ : regenerated cellulose $(2 \mathrm{~g})$ was immersed in the mixture of pyridine $(30 \mathrm{ml})$ and water $(10 \mathrm{ml})$ in order to activate itself. Then the activated cellulose was immersed in pyridine for 2 hours to remove the remained water. After this operation was repeated four times, tosyl chloride $(14 \mathrm{~g})$ was added to the activated cellulose and the reaction was continued for seven days at room temperature. The products were precipitated in ethanol and washed with ethanol using Soxhlet extraction for 24 hours. $\overline{D P}$ of CellOTs (DS of OTs $=2.8$ ) was 21. Solvents such as DMF, nitrobenzene and benzonitrile were purified by conventional methods. Commercial potassium iodide and potassium bromide were used without further purification.

\section{Graft Polymerization of 2-Oxazolines on Cel- lulose Derivatives}

Graft polymerization was carried out in a pear-shaped flask equipped with a three-way cock under a dry nitrogen atmosphere. Cellulose derivative $(0.4 \mathrm{~g})$ was dissolved in a polar solvent $(8-20 \mathrm{ml})$ and then a monomer (2- $4 \mathrm{ml}$ ) and internal standard regent of gas chromatography $(2 \mathrm{ml})$ were added to the solution. The solution was heated at $100^{\circ} \mathrm{C}$ (with $\mathrm{MeOXZ}$ ) or $90^{\circ} \mathrm{C}$ (with $\mathrm{OXZ}$ ) for 24 hours with stirring. After the reaction, the products were precipitated in ether, filtered off and washed with water to remove the homopolymer of 2-oxazolines using Soxhlet extraction above 24 hours. Conversion of 2-oxazolines was determined from the residual monomer concentration by gas chromatography using bromobenzene or tetraline as internal standard. The composition of copolymers (represented by the molar ratio of monomer unit to 
cellulose derivative unit, [monomer]/[cellulose derivative]) was assayed by nitrogen analysis, the Kjeldahl's method being used and calculated from eq 1.

[monomer]/[cellulose derivative] in copolymer

$$
=\frac{N \times \text { unit molecular weight of cellulose derivative }}{1400-N \times \text { molecular weight of monomer }}
$$

$(N: \mathrm{N} \%$ of copolvmer)

Isolation of Branched Poly(MeOXZ) from Copolymers

Isolation of branched poly(MeOXZ) from copolymers $(0.3 \mathrm{~g})$ synthesized by the graft polymerization of $\mathrm{MeOXZ}$ on AcCell-AcX were carried out in the following manner: (1) swelling in $75 \%$ aqueous ethanol $(10 \mathrm{ml})$ at $50-60^{\circ} \mathrm{C}$ for 30 minutes, (2) addition of $0.5 \mathrm{~N}$ $\mathrm{NaOH}(16 \mathrm{ml})$ and (3) heating on the steam bath for 10 minutes and standing at room temperature for 24 hours. Acetyl groups of AcCell-AcX will be hydrolyzed by this reaction, resulting in the separation of branched poly(MeOXZ). After the reaction, the solution was neutralized with $1 \mathrm{~N} \mathrm{HCl}$, concentrated, exchanged water with methanol and poured into chloroform. Salts formed were filtered off and the filtrate was concentrated. Branched poly $(\mathrm{MeOXZ})$ precipitated by addition of the concentrated filtrate into ether.

\section{Determination of Molecular Weight}

Number-average molecular weights $\left(\bar{M}_{n}\right)$ of cellulose derivatives and branched poly (MeOXZ) were measured by gel permeation chromatography (GPC; Toyo Soda Model HLC-803D, GMHXL polystyrene gel columns, DMF solution). Mn was calculated from GPC curves on the basis of a polyethyleneoxide calibration.

\section{RESULTS AND DISCUSSION}

\section{Graft Polymerization of $\mathrm{MeOXZ}$ on Cell-Cl}

Effect of KI Addition on Graft Polymerization. In the ring-opening polymerization of MeOXZ, it has been shown that the po- lymerization initiated by iodide or bromide compounds such as methyl iodide and benzyl bromide proceeds via ionic propagating spesies 1 but that initiated by chlorine compounds proceeds via covalent species $\mathbf{2}$ due to the nucleophilicity of halogen anion. ${ }^{17}$ Accordingly, the rate of polymerization of the former is larger than that of the latter. With chlorine compounds, however, it is possible to en-

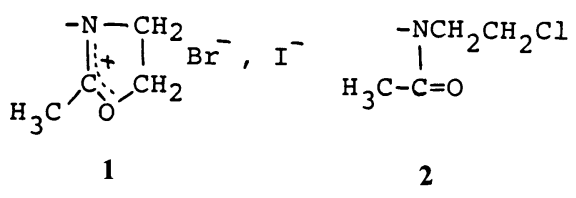

large the rate of polymerization of $\mathrm{MeOXZ}$ by the addition of salts such as potassium iodide due to the anion-exchange reaction.

Then, the graft polymerization of $\mathrm{MeOXZ}$ on Cell-Cl was carried out in the presence of potassium iodide. Figure 1 shows that the graft polymerization hardly occurred in the absence

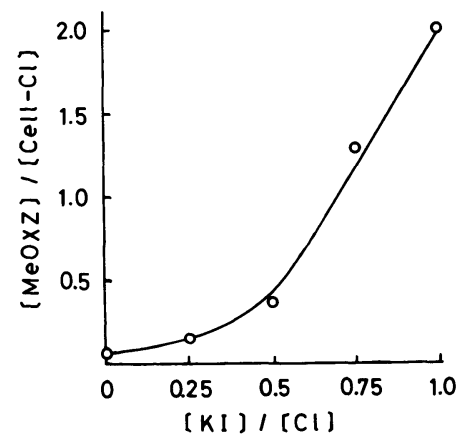

Figure 1. Acceleration of graft polymerization of $\mathrm{MeOXZ}$ on Cell-Cl by addition of $\mathrm{KI}$ : [Cell- $\mathrm{Cl}\left(\mathrm{Cl}^{\%} \%=\right.$ 16.6)], $0.10 \mathrm{moll}^{-1}$; [MeOXZ], $1 \mathrm{moll}^{-1}$; DMF, $20 \mathrm{ml}$; temp, $100^{\circ} \mathrm{C}$; time, $24 \mathrm{~h}$. 


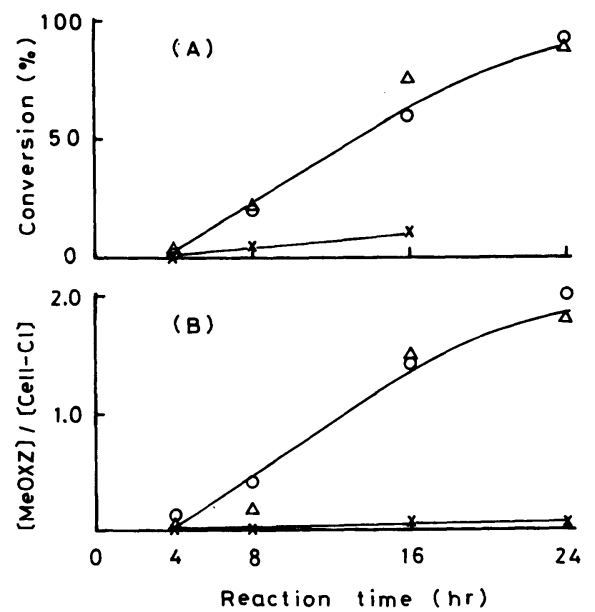

Figure 2. Effect of reaction temperature on the rates of polymerization (A) and graft polymerization (B) of MeOXZ: [Cell-Cl(Cl\%=26.1)], $0.09 \mathrm{moll}^{-1}$; [MeOXZ], $1 \mathrm{moll}^{-1} ;[\mathrm{KI}] /[\mathrm{Cl}]=1.0 ; \mathrm{DMF}, 20 \mathrm{ml}$. Temperature: (O) $100^{\circ} \mathrm{C} ;(\triangle) 80^{\circ} \mathrm{C} ;(\times) 60^{\circ} \mathrm{C}$.

of potassium iodide and that the molar ratio of $[\mathrm{MeOXZ}] /[\mathrm{Cell}-\mathrm{Cl}]$ increased with an increase in the amount of potassium iodide. This shows that the halogen-exchange reaction of $\mathrm{Cl}$ to $\mathrm{I}$ is necessary to initiate this graft polymerization.

Effect of Reaction Temperature on the Rate of Graft Polymerization. The graft polymerization of $\mathrm{MeOXZ}$ on Cell-Cl was carried out at 60,80 , and $100^{\circ} \mathrm{C}$ in the presence of potassium iodide of equimolar amounts with $\mathrm{Cl}$. The curves of the rate of polymerization and the rate of graft polymerization were shown in Figure 2. MeOXZ hardly polymerized at $60^{\circ} \mathrm{C}$, but easily polymerized at $80^{\circ} \mathrm{C}$ and $100^{\circ} \mathrm{C}$. The rates of polymerization over $80^{\circ} \mathrm{C}$ were not affected by the temperature. The grafting efficiency of $\mathrm{MeOXZ}$, defined by eq 2, was about $20 \%$ at each reaction time.

grafting efficiency $(\%)$

$$
=\frac{\text { the amount of grafted } \mathrm{MeOXZ}}{\text { the amount of polymerized } \mathrm{MeOXZ}} \times 100
$$

Effect of Monomer Concentration on Graft Polymerization. The graft polymerization of

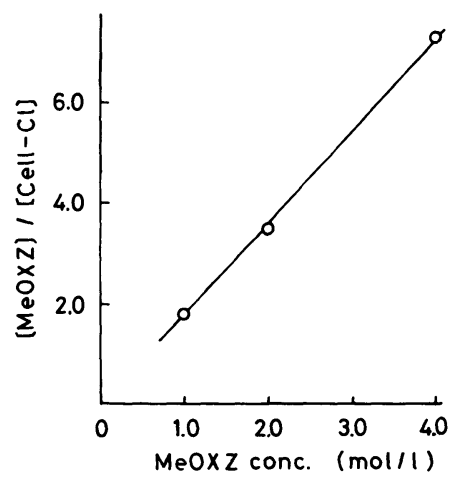

Figure 3. Effect of $\mathrm{MeOXZ}$ concentration on graft polymerization of $\mathrm{MeOXZ}$ on Cell- $\mathrm{Cl}$ : [Cell- $\mathrm{Cl}(\mathrm{Cl} \%=$ 26.1)], $0.18 \mathrm{moll}^{-1} ;[\mathrm{KI}] /[\mathrm{Cl}]=1.0$; solvent; DMF; temp, $100^{\circ} \mathrm{C}$; time, $24 \mathrm{~h}$.

Table I. Graft polymerization of $\mathrm{MeOXZ}$ on Cell- $\mathrm{Cl}$ in various solvents ${ }^{\mathrm{a}}$

\begin{tabular}{lcc}
\hline \multirow{2}{*}{ Solvent } & \multicolumn{2}{c}{ Copolymer composition } \\
\cline { 2 - 3 } & $\mathrm{N} / \%$ & {$[\mathrm{MeOXZ}] /[$ Cell-Cl] } \\
\hline DMF & 12.6 & 7.3 \\
Nitrobenzene & 11.1 & 4.7 \\
Benzonitrile & 11.9 & 5.8 \\
\hline
\end{tabular}

a $[\mathrm{Cell}-\mathrm{Cl}(\mathrm{Cl} \%=26.1)], \quad 0.18 \mathrm{moll}^{-1} ; \quad[\mathrm{MeOXZ}], 3.9$ moll ${ }^{-1}$; solvent, $8 \mathrm{ml} ;[\mathrm{KI}] /[\mathrm{Cl}]=1.0$; temp, $100^{\circ} \mathrm{C}$; time, $24 \mathrm{~h}$.

MeOXZ on Cell-Cl was carried out in the presence of potassium iodide of equimolar amounts with $\mathrm{Cl}$ at various $\mathrm{MeOXZ}$ concentrations in DMF. As shown in Figure 3, $[\mathrm{MeOXZ}] /[\mathrm{Cell}-\mathrm{Cl}]$ increased proportionally with an increase in $\mathrm{MeOXZ}$ concentration.

Effect of Solvent on Graft Polymerization. The graft polymerization of MeOXZ on Cell$\mathrm{Cl}$ was carried out in nitrobenzene and benzonitrile, as well as DMF. As shown in Table I, $[\mathrm{MeOXZ}] /[\mathrm{Cell}-\mathrm{Cl}]$ revealed the maximum value in DMF. This is probably due to the difference of solubility of Cell- $\mathrm{Cl}$ and copolymer in the three solvents. It is to be noted that the graft polymerization did not occur in the absence of potassium iodide in any solvent. 
Table II. Graft polymerization of MeOXZ on AcCell-AcX in the presence or absence of potassium salts in $\mathrm{DMF}^{\mathrm{a}}$

\begin{tabular}{|c|c|c|c|c|c|c|}
\hline \multirow{2}{*}{$\mathrm{AcX}$} & \multirow{2}{*}{ Salt } & $\begin{array}{l}\text { Conversion } \\
\text { of } \mathrm{MeOXZ}\end{array}$ & \multirow{2}{*}{$\begin{array}{c}{[\mathrm{MeOXZ}] /[\text { AcCell-AcX] }} \\
\text { in copolymer }\end{array}$} & \multirow{2}{*}{$\frac{\begin{array}{c}\text { Grafting } \\
\text { efficiency }\end{array}}{\%}$} & \multirow{2}{*}{$\begin{array}{c}\bar{M}_{n} \text { of branched } \\
\text { poly }(\mathrm{MeOXZ})\end{array}$} & \multirow{2}{*}{$\begin{array}{c}\begin{array}{c}\text { Apparent initiator } \\
\text { efficiency }\end{array} \\
\%\end{array}$} \\
\hline & & $\%$ & & & & \\
\hline \multirow[t]{3}{*}{$\mathrm{AcCl}$} & - & 29 & 1.0 & 22 & 570 & 55 \\
\hline & $\mathrm{KBr}$ & 64 & 2.3 & 23 & 1110 & 65 \\
\hline & KI & 94 & 3.9 & 26 & 1430 & 86 \\
\hline \multirow[t]{2}{*}{$\mathrm{AcBr}$} & - & 78 & 2.2 & 16 & 1070 & 43 \\
\hline & KI & 99 & 3.3 & 19 & 1350 & 51 \\
\hline AcI & - & - & 3.7 & - & 1580 & 54 \\
\hline
\end{tabular}

${ }^{\mathrm{a}}$ [AcCell-AcX], $0.06 \mathrm{moll}^{-1}$; DS of AcX, AcCl: 0.27, AcBr: 0.41, AcI: 0.37; [MeOXZ], 1 moll ${ }^{-1}$; DMF, 20 ml; temp, $100^{\circ} \mathrm{C}$; time, $24 \mathrm{~h}$.

\section{Graft Polymerization of 2-Oxazolines on AcCell-AcX}

Effect of the Kind of AcX and the Addition of Salts on Graft Polymerization. The graft polymerization of $\mathrm{MeOXZ}$ and $\mathrm{OXZ}$ on AcCell-AcX, where $\mathrm{X}$ is composed of $\mathrm{Cl}, \mathrm{Br}$ or I was carried out in the presence or absence of potassium salts. Though MeOXZ cannot graft-polymerize on $\mathrm{Cell}-\mathrm{Cl}$ in the absence of potassium iodide as mentioned in previous section, it can graft-polymerize on AcCell- $\mathrm{AcCl}$ under the same conditions as shown in Table II. This is presumably due to the large reactivity of $\alpha$-chloroesters of $\mathrm{AcCell}-\mathrm{AcCl}$ in the nucleophile reaction of MeOXZ.

MeOXZ polymerized more easily in the presence of $\mathrm{KBr}$ or $\mathrm{KI}$ resulting in the higher $\mathrm{MeOXZ}$ conversion and [MeOXZ]/[AcCell$\mathrm{AcCl}$. These values were in the order of nonsalt $<\mathrm{KBr}<\mathrm{KI}$, namely $\mathrm{Cl}^{-}<\mathrm{Br}^{-}<\mathrm{I}^{-}$as a counter anion of propagating species. Though the polymerization of $\mathrm{MeOXZ}$ was easily initiated by $\mathrm{AcCell}-\mathrm{AcCl}$, it is considered that it was also easily terminated because of the large nucleophilicity of $\mathrm{Cl}^{-}$ion. As a result, this graft polymerization is considered to be affected by the nucleophilicity of halogen ions compared with that of $\mathrm{MeOXZ}$, $\mathrm{Cl}^{-}>\mathrm{MeOXZ}>\mathrm{Br}^{-}>\mathrm{I}^{-} .{ }^{1}$ Accordingly with AcCell-AcBr MeOXZ polymerized sufficiently
Table III. Graft polymerization of $\mathrm{OXZ}$ on AcCell-AcX in DMF ${ }^{a}$

\begin{tabular}{lccc}
\hline & $\begin{array}{c}\text { Conversion } \\
\text { of } \mathrm{OXZ}\end{array}$ & $\begin{array}{c}\text { [OXZ]/[AcCell-AcX] } \\
\text { in copolymer }\end{array}$ & $\begin{array}{c}\text { Grafting } \\
\text { efficiency }\end{array}$ \\
\cline { 2 - 2 } & $\%$ & & $\%$ \\
\hline $\mathrm{AcCl}$ & 2.5 & 0.04 & 8 \\
$\mathrm{AcBr}$ & 2.7 & 0.06 & 11 \\
$\mathrm{AcI}$ & - & 0.09 & - \\
\hline
\end{tabular}

a Polymerization conditions are the same as in Table II except that the reaction temperature is $90^{\circ} \mathrm{C}$.

without the addition of $\mathrm{KI}$ but [MeOXZ]/ [AcCell-AcBr] enlarged further in the presence of $\mathrm{KI}$.

Thus the graft polymerization of $\mathrm{MeOXZ}$ on AcCell-AcX proceeded easily in the order of $\mathrm{Cl}^{-}<\mathrm{Br}^{-}<\mathrm{I}^{-}$counter anion, that is in the reverse order of nucleophilicity of anions.

On the other hand, the polymerization of OXZ hardly occurred with any AcCell-AcX as shown in Table III. This is probably due to smaller nucleophilicity of $\mathrm{OXZ}$ compared with that of the three halogen anions. ${ }^{1}$

Then the graft copolymers were hydrolyzed according to the method mentioned in the experimental section in order to isolate the branched polymer. No nitrogen was detected from the remaining polymer by elemental analysis and the polymer recovered from solution 
was well confirmed to be poly(MeOXZ) by IR and ${ }^{1} \mathrm{H}$ NMR spectra. As shown in Table II, the molecular weight $\left(\bar{M}_{n}\right)$ of branched poly(MeOXZ) determined by GPC was less than 1580 (DP, 18.6) and was in the order of
$\mathrm{Cl}^{-}<\mathrm{Br}^{-}<\mathrm{I}^{-}$. The order of apparent initiator efficiency of halogen acetyl group calculated from equation (3) was also consistent with this order.

apparent initiator efficiency $(\%)=$

$[\mathrm{MeOXZ}] /[$ AcCell-AcX $]$ in copolymer $\times 8500$

degree of substitution (DS) of AcX $\times \bar{M}_{n}$ of branched poly(MeOXZ)

From these results, it is apparent that the ease of graft polymerization of $\mathrm{MeOXZ}$ on AcCell-AcX increases with decreasing nucleophilicity of halogen ions.

Effect of the DS of AcX. The graft polymerization of $\mathrm{MeOXZ}$ was carried out with AcCell-AcX having different DS of AcX. Table IV shows that the conversion of $\mathrm{MeOXZ}$ and $[\mathrm{MeOXZ}] /[$ AcCell-AcX] increased with an increase in the DS of AcX, that is, the initiator concentration. $\bar{M}_{n}$ of branched poly(MeOXZ), however, decreased with increasing in the DS of AcX resulting in an increase in the apparent initiator efficiency. This means that the graft copolymers have shorter and numerous branched poly $(\mathrm{MeOXZ})$ chains on increasing the DS of AcX.

Effect of $\mathrm{MeOXZ}$ Concentration. The graft polymerization of $\mathrm{MeOXZ}$ on AcCell-AcBr was carried out at various $\mathrm{MeOXZ}$ concentrations. As shown in Table $\mathrm{V},[\mathrm{MeOXZ}] /$ [AcCell-AcBr] and $\bar{M}_{n}$ of branched poly(MeOXZ) increased with increasing MeOXZ concentration, but the apparent initiator efficiency of $\mathrm{AcBr}$ was almost constant. This means that the graft copolymers have longer branched chains with increasing $\mathrm{MeOXZ}$ concentration resulting in an increase in

Table IV. Graft polymerization of MeOXZ on AcCell-AcX having various DS of AcX in DMF

\begin{tabular}{|c|c|c|c|c|c|c|}
\hline \multirow{2}{*}{ AcX } & \multirow{2}{*}{ DS of AcX } & $\begin{array}{l}\text { Conversion } \\
\text { of } \mathrm{MeOXZ}\end{array}$ & \multirow{2}{*}{$\begin{array}{c}{[\mathrm{MeOXZ}] /[\text { AcCell-AcX] }} \\
\text { in copolymer }\end{array}$} & \multirow{2}{*}{$\begin{array}{c}\begin{array}{c}\text { Grafting } \\
\text { efficiency }\end{array} \\
\%\end{array}$} & \multirow{2}{*}{$\begin{array}{c}\bar{M}_{n} \text { of branched } \\
\text { poly }(\mathrm{MeOXZ})\end{array}$} & \multirow{2}{*}{$\begin{array}{l}\begin{array}{c}\text { Apparent initiator } \\
\text { efficiency }\end{array} \\
\frac{\%}{\%}\end{array}$} \\
\hline & & $\%$ & & & & \\
\hline \multirow[t]{3}{*}{$\mathrm{AcBr}$} & 0.22 & 27 & 0.8 & 18 & 1130 & 26 \\
\hline & 0.41 & 78 & 2.2 & 16 & 1070 & 43 \\
\hline & 0.62 & 65 & 4.2 & 34 & 800 & 71 \\
\hline \multirow[t]{2}{*}{ AcI } & 0.19 & 92 & 2.9 & 19 & 3510 & 37 \\
\hline & 0.37 & - & 3.7 & - & 1580 & 54 \\
\hline
\end{tabular}

a $\left[\right.$ AcCell-AcX], 0.05-0.06 $\mathrm{moll}^{-1}$; [MeOXZ], $1 \mathrm{moll}^{-1}$; DMF, $20 \mathrm{ml}$; temp, $100^{\circ} \mathrm{C}$; time, $24 \mathrm{~h}$.

Table V. Graft polymerization of $\mathrm{MeOXZ}$ on $\mathrm{AcCell}-\mathrm{AcBr}$ at various $\mathrm{MeOXZ}$ concentrations in $\mathrm{DMF}^{\mathrm{a}}$

\begin{tabular}{|c|c|c|c|c|c|}
\hline$\frac{\mathrm{MeOXZ} \text { conc. }}{\mathrm{moll}^{-1}}$ & $\begin{array}{c}\begin{array}{c}\text { Conversion } \\
\text { of } \mathrm{MeOXZ}\end{array} \\
\%\end{array}$ & $\begin{array}{c}{[\mathrm{MeOXZ}] /[\mathrm{AcCell}-\mathrm{AcBr}]} \\
\text { in copolymer }\end{array}$ & $\begin{array}{c}\begin{array}{c}\text { Grafting } \\
\text { efficiency }\end{array} \\
\frac{0}{\%}\end{array}$ & $\begin{array}{c}\bar{M}_{n} \text { of branched } \\
\text { poly }(\mathrm{MeOXZ})\end{array}$ & $\begin{array}{c}\begin{array}{l}\text { Apparent } \\
\text { efficiency }\end{array} \\
\frac{\%}{\%}\end{array}$ \\
\hline 0.25 & 61 & 1.7 & 58 & 380 & 60 \\
\hline 0.5 & 61 & 2.3 & 40 & 550 & 58 \\
\hline 1.0 & 65 & 4.2 & 34 & 800 & 71 \\
\hline
\end{tabular}

a $[\mathrm{AcCell}-\mathrm{AcBr}(\mathrm{DS}$ of $\mathrm{AcBr}=0.62)], 0.05 \mathrm{moll}^{-1}$; DMF, $20 \mathrm{ml}$; temp, $100^{\circ} \mathrm{C}$; time, $24 \mathrm{~h}$. 
Table VI. Graft polymerization of 2-oxazolines on Cell-OTs in various solvents ${ }^{\mathrm{a}}$

\begin{tabular}{|c|c|c|c|c|}
\hline \multirow{2}{*}{ Monomer } & \multirow{2}{*}{ Solvent } & $\begin{array}{l}\text { Conversion } \\
\text { of monomer }\end{array}$ & \multirow{2}{*}{$\begin{array}{c}\text { [Monomer]/[Cell-OTs] } \\
\text { in copolymer }\end{array}$} & \multirow{2}{*}{$\begin{array}{c}\begin{array}{c}\text { Grafting } \\
\text { efficiency }\end{array} \\
\% \%\end{array}$} \\
\hline & & $\%$ & & \\
\hline \multirow[t]{3}{*}{$\mathrm{MeOXZ}$} & DMF & 32 & 2.9 & 28 \\
\hline & Nitrobenzene & 53 & 5.0 & 27 \\
\hline & Benzonitrile & 94 & 6.1 & 18 \\
\hline \multirow[t]{3}{*}{ OXZ } & DMF & 2 & 0.7 & 84 \\
\hline & Nitrobenzene & 12 & 1.2 & 24 \\
\hline & Benzonitrile & 6 & 1.3 & 57 \\
\hline
\end{tabular}

${ }^{\text {a }}$ [Cell-OTs $(\mathrm{DS}$ of OTs $\left.=2.8)\right], 0.03 \mathrm{moll}^{-1}$; [monomer], $1 \mathrm{~mol} 1^{-1}$; solvent, $20 \mathrm{ml}$; temp, $100^{\circ} \mathrm{C}(\mathrm{MeOXZ})$ or $90^{\circ} \mathrm{C}$ (OXZ); time, $24 \mathrm{~h}$.

\section{[MeOXZ]/[AcCell-AcBr].}

Graft Polymerization of 2-Oxazolines on CellOTs

The graft polymerization of $\mathrm{MeOXZ}$ and OXZ on Cell-OTs was carried out in DMF, nitrobenzene and benzonitrile. Both monomers graft-polymerized on Cell-OTs in these three solvents and the molar ratio of [monomer]/[Cell-OTs] was greater with $\mathrm{MeOXZ}$ than with OXZ as shown in Table VI. OXZ did not graft-polymerize on AcCell-AcX as shown in Table III, but graft-polymerized on Cell-OTs.

On the graft polymerization of $\mathrm{MeOXZ}$ on Cell-OTs having various DS of OTs groups in benzonitrile, [MeOXZ]/[Cell-OTs] was almost constant in the range of DS 1.7 to 2.8 . This is probably due to the sufficient concentration range for this initiator to reach maximum [MeOXZ]/[Cell-OTs]. Figure 4 shows ${ }^{1} \mathrm{H}$ NMR spectra of the copolymer and Cell-OTs. The spectrum of the copolymer revealed a characteristic peak of acetyl group in poly $(\mathrm{MeOXZ})$ at about $2.0 \mathrm{ppm}$.

Then the copolymer was hydrolyzed in $c a$. $8 \%$ sodium hydroxide solution at $100^{\circ} \mathrm{C}$ for 48 hours to convert the grafted poly(MeOXZ) to PEI according to the Saegusa's method. ${ }^{7}$ The copolymer composed of $87 \mathrm{~mol} \%$ poly(MeOXZ) was acertained to contain 85 $\mathrm{mol} \% \mathrm{PEI}$ after hydrolysis from the elemental

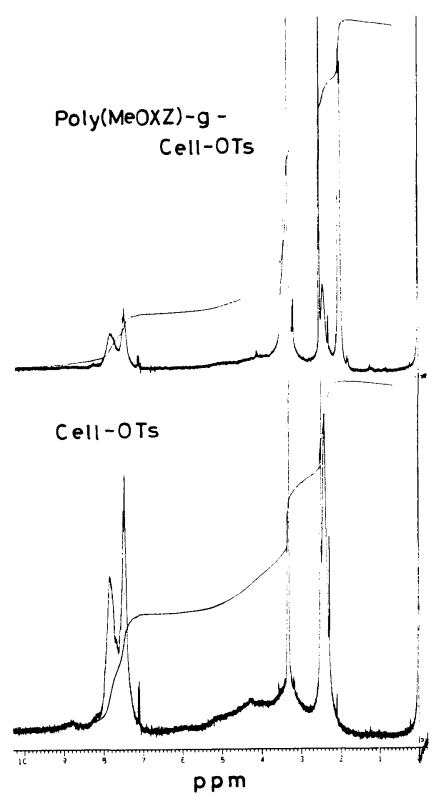

Figure 4. ${ }^{1} \mathrm{H}$ NMR spectra of Cell-OTs and poly(MeOXZ)- $g$-Cell-OTs in DMSO- $d_{6}$ (recorded on JEOL-GX 270 spectrometer).

analysis. Futher, the ${ }^{1} \mathrm{H}-\mathrm{NMR}$ spectrum of the copolymer revealed a new peak of the methylene group in PEI at about $2.8 \mathrm{ppm}$ instead of the dissapearance of acetyl peak in poly $(\mathrm{MeOXZ}) .^{18}$

From these results, it is apparent that the graft copolymers composed of linear PEI as branched polymer could be synthesized by this method. These graft copolymers have well- 
defined structures different from the copolymers synthesized by the reaction of Cell-OTs with commercial PEI constituted of branched structure. ${ }^{9}$

\section{REFERENCES}

1. T. Saegusa, H. Ikeda, and H. Fujii, Polym. J., 3, 176 (1972).

2. M. Miyamoto, Y. Sano, T. Saegusa, and S. Kobayashi, Eur. Polym. J., 19, 955 (1983).

3. T. Saegusa and H. Ikeda, Macromolecules, 6, 805 (1973).

4. S. Kobayashi, M. Kaku, and T. Saegusa, Polym. Prepr. Jpn., 32, 1403 (1983).

5. S. Kobayashi, Y. Shimano, and T. Saegusa, Polym. Prepr. Jpn., 33, 1311 (1984).

6. T. Saegusa, S. Kobayashi, and A. Yamada, Polym. J., 11, 53 (1978).

7. T. Saegusa, S. Kobayashi, and A. Yamada, Macromolecules, 8, 390 (1975).

8. S. Kobayashi, M. Kaku, M. Kyogaku, and T.
Saegusa, Polym. Prepr. Jpn., 33, 1315 (1984).

9. I. Ikeda, K. Arai, F. Tonomori, and K. Suzuki, Sen-i Gakkaishi, 42, T-356 (1986).

10. I. Ikeda, H. Yamauchi, and K. Suzuki, Sen-i Gakkaishi, 43, 166 (1987).

11. H. Wenker, J. Am. Chem. Soc., 57, 1079 (1935); ibid., 60, 2152 (1938).

12. F. Franco and J. M. Muchowski, J. Heterocycl. Chem., 17, 1613 (1980).

13. T. Saegusa, H. Ikeda, and H. Fujii, Polym. J., 3, 35 (1972).

14. T. Ishii, A. Ishizu, and J. Nakano, Carbohydr. Res., 59, 155 (1977).

15. G. D. Hiatt, J. W. Mench, and B. Fulkerson, Ind. Eng. Chem. Prod. Res. Develop., 3, 295 (1964).

16. D. H. Chambell, E. Luescher, and L. S. Leraman, Proc. Natl. Acad. Sci. U.S.A., 37, 575 (1954); J. B. Robbins, J. Haimovichi, and M. Sela, Immunochemistry, 4, 11 (1967).

17. T. Saegusa, S. Kobayashi, and A. Yamada, Makromol. Chem., 177, 2271 (1976).

18. T. Saegusa, H. Ikeda, and H. Fujii, Macromolecules, 5, 108 (1972). 